\title{
Pyoderma gangrenosum coexisting with a myeloproliferative disorder
}

\section{Piodermia zgorzelinowa współistniejąca z zespołem mieloproliferacyjnym}

\author{
Aleksandra Kapuśniak, Aleksandra Czachor, Grażyna Wąsik \\ General and Oncological Dermatology Ward with a day care unit, Provincial Hospital, Opole, Poland \\ Oddział Dermatologii Ogólnej i Onkologicznej z Pododdziałem Dziennym, Szpital Wojewódzki, Opole, Polska \\ Dermatol Rev/Przegl Dermatol 2020, 107, 44-51 \\ DOI: https://doi.org// 0.5। I4/dr.2020.93970
}

\author{
CORRESPONDING AUTHOR/ \\ ADRES DO KORESPONDENCJI: \\ lek. med. Aleksandra Kapuśniak \\ Oddział Dermatologii \\ Ogólnej i Onkologicznej \\ z Pododdziałem Dziennym \\ Szpital Wojewódzki \\ ul. Kośnego 53 \\ 45-372 Opole \\ tel.: +48501672062 \\ e-mail: kapusniaka@poczta.fm
}

\begin{abstract}
Introduction. Pyoderma gangrenosum is a disease in the group of neutrophilic dermatoses, which is characterized by cutaneous lesions in the form of rapidly spreading ulcerations with elevated edges and a necrotic central par. Histopathology shows inflammatory infiltrates consisting mainly of mature multinucleated leukocytes. Pyoderma gangrenosum is often accompanied by systemic diseases, such as inflammatory bowel diseases, autoimmune connective tissue diseases, internal organs and hematologic malignancies, especially myeloproliferative disorder, acute and chronic leukemic myelosis and multiple myeloma.
\end{abstract}

Objective. To present a patient with pyoderma gangrenosum concurrent with myeloproliferative disorder and progression of the disease after a surgical intervention.

Case report. The patient, aged 78, was referred from the General Surgical Ward in Nysa with the diagnosis of right buttock necrosis in an extensive inflammatory infiltration where an incision was made and the wound of the right buttock was drained. Computed tomography scan excluded a buttock abscess. The patient was admitted to the Dermatologic Ward in Opole. At admission he presented with a large lesion on the right buttock and right hip area, with central ulceration and an elevated periphery. Three incisions after a surgical intervention were visible. Laboratory tests showed increased serum levels of inflammatory parameters and pancytopenia. Hospital treatment included antibiotic therapy, intravenous steroid pulses, glucocorticosteroids per os and topical glucocorticosteroid ointments and specialized dressings. The patient was consulted hematologically on a number of occasions. After improvement of morphotic parameters and local condition the patient was discharged with an indication to broaden the hematological diagnostics for myeloproliferative disorder.

Conclusions. Pyoderma gangrenosum is often accompanied by systemic diseases, which is why a holistic approach to the patient, looking for concurrent diseases and their treatment, is important. Correct diagnosis of the disease prevents unnecessary surgical interventions, which may lead to enlargement of the ulceration. The patient required broadened hematological diagnostics which lead to the diagnosis of myeloproliferative disorder. 


\section{STRESZCZENIE}

Wprowadzenie. Piodermia zgorzelinowa jest chorobą z grupy dermatoz neutrofilowych. Charakteryzuje się występowaniem zmian skórnych w postaci szybko szerzących się owrzodzeń o wyniosłych brzegach i martwiczym dnie. W obrazie histopatologicznym widoczne są nacieki zapalne złożone głównie z dojrzałych, wielojądrzastych leukocytów. Piodermii zgorzelinowej często towarzyszą choroby układowe, takie jak nieswoiste zapalenie jelit, autoimmunologiczne choroby tkanki łącznej, nowotwory złośliwe narządów wewnętrznych i układu krwiotwórczego, zwłaszcza zespoły mieloproliferacyjne, ostre i przewlekłe białaczki szpikowe oraz szpiczak mnogi.

Cel pracy. Przedstawienie przypadku pacjentki z piodermią zgorzelinową współwystępującą z zespołem mieloproliferacyjnym oraz progresji choroby w wyniku interwencji chirurgicznej.

Opis przypadku. Pacjentka, lat 78, została skierowana z Oddziału Chirurgii Ogólnej Szpitala w Nysie z rozpoznaniem martwicy prawego pośladka w obrębie rozległego nacieku zapalnego po wykonaniu nacięcia i drenażu rany. Za pomocą tomografii komputerowej wykluczono ropień pośladka. Ze względu na progresję zmian skórnych chora została przyjęta na Oddział Dermatologii Szpitala Wojewódzkiego w Opolu. Przy przyjęciu u pacjentki stwierdzono rozległe owrzodzenie z martwiczym dnem, sine na obwodzie, umiejscowione na prawym pośladku i prawym biodrze. Widoczne były również trzy nacięcia po interwencji chirurgicznej. Badania laboratoryjne wykazały podwyższone parametry zapalne i pancytopenię. W leczeniu szpitalnym zastosowano antybiotykoterapię, leki glikokortykosteroidowe podawane w pulsach dożylnych i doustnie, miejscowe maści glikokortykosteroidowe oraz opatrunki specjalistyczne. Pacjentkę kilkukrotnie konsultowano hematologicznie. Po uzyskaniu poprawy parametrów morfotycznych i stanu miejscowego kobietę wypisano do domu z zaleceniem rozszerzenia diagnostyki hematologicznej $\mathrm{w}$ kierunku zespołu mieloproliferacyjnego.

Wnioski. Piodermii zgorzelinowej często towarzyszą choroby układowe. $Z$ tego względu istotne jest holistyczne podejście do pacjenta, poszukiwanie chorób współistniejących oraz ich leczenie. Właściwe rozpoznanie tej jednostki chorobowej zapobiega zbędnym interwencjom chirurgicznym, które najczęściej prowadzą do progresji owrzodzenia. Pacjentka wymagała rozszerzonej diagnostyki hematologicznej, dzięki której ustalono rozpoznanie zespołu mieloproliferacyjnego.

Key words: pyoderma gangrenosum, myeloproliferative syndrome, neutrophilic dermatoses.

Słowa kluczowe: piodermia zgorzelinowa, zespół mieloproliferacyjny, dermatoza neutrofilowa.

\section{INTRODUCTION}

Pyoderma gangrenosum is a rare disease from the group of neutrophilic dermatoses due to the large neutrophilic infiltrations on the skin and thus leading to secondary damage of vessels. Even though neutrophilic infiltrations in pyoderma gangrenosum are present in tissues bacterial infections do not play

\section{WPROWADZENIE}

Piodermia zgorzelinowa jest rzadką chorobą należącą do grupy dermatoz neutrofilowych ze względu na powstawanie na skórze rozległych nacieków z neutrofilów prowadzących do wtórnego uszkodzenia naczyń. Choć w przebiegu piodermii zgorzelinowej w tkankach obecne są nacieki z neutrofilów, zakaże- 
a direct role in its pathogenesis. Culture of skin and blood are always negative. Antibiotic therapy does not influence the course of the disease. It is believed that proinflammatory cytokines and growth factors take part in the process [1]. Pyoderma gangrenosum at first takes the form of a small disorder imitating a furunculus or a cyst, a small pustule, which becomes necrotic and rapidly evolves into a large ulceration. The disorder creates ulcers rapidly and spreads in a circumferential fashion, creating a large but relatively topical ulceration with a swollen necrotic ulcer bed and heaped up ruby red edges. The edges are usually undermined, blue-erythematous or violet, irregular, heaped up with presence of fistulas, partially covered with a necrotic eschar, with presence or absence of granulation tissue. Pustules are present in the active edge as well as in the bottom of the ulceration $[2,3]$.

The ulceration is sometimes preceded by an inflammatory infiltration or a cystic reaction [4]. The skin disorders disappear, leaving scars; the scars created in the healing process are described as sieve-like with numerous tiny holes and pits $[2,3]$. One of the symptoms of pyoderma gangrenosum is pathergy changed reactivity, which consists of appearance of skin disorders due to injuries, often very minor. Pathergy is present in $25 \%$ of pyoderma gangrenosum. If the disease is not properly diagnosed and is radically surgically treated it will progress in circumferential fashion [5]. So in a case of a suspicion of pyoderma gangrenosum it is contraindicated to conduct any procedures because they can have a negative effect on the progress of the disease. Pyoderma gangrenosum is often accompanied by systemic diseases, such as inflammatory bowel disease, autoimmune connective tissue diseases, internal organ and hematopoietic system malignancies, especially myeloproliferative disorder (MPD), acute and chronic leukemic myelosis and multiple myeloma [6, 7]. Presence of other diseases influences the progression of pyoderma gangrenosum and the prognosis of the underlying pathology influences it as well. If the underlying disease is treatable, the prognosis is good; if not, the treatment of the disease is much worse.

\section{OBJECTIVE}

To present a patient with pyoderma gangrenosum concurrent with myeloproliferative disorder and the progression of the disease due to a surgical intervention.

\section{CASE REPORT}

The 78-years old woman was admitted to the Dermatologic Ward in February 2018 due to progression nia bakteryjne nie odgrywają bezpośredniej roli w jej patogenezie. Posiewy ze zmian skórnych i krwi są zawsze ujemne, a antybiotykoterapia nie ma wpływu na przebieg choroby. Uważa się, że w procesie chorobowym biorą udział cytokiny prozapalne i czynniki wzrostu [1]. Piodermia zgorzelinowa ma początkowo postać niewielkiej zmiany przypominającej czyraka lub torbiel - drobnej krosty, która ulega martwicy i w krótkim czasie przekształca się w rozległe owrzodzenie. Szybko wrzodziejąca zmiana rozprzestrzenia się obwodowo, tworząc rozległe, ale stosunkowo ograniczone miejscowo owrzodzenie z obrzękniętym, martwiczym dnem i wyniosłymi, ciemnoczerwonymi brzegami. Brzegi są zazwyczaj podminowane, wałowate, sinorumieniowe lub fioletowe. Stwierdza się także przetoki częściowo pokryte martwiczym strupem, z obecnością lub bez obecności tkanki ziarnistej. Zarówno w obrębie aktywnego brzegu, jak i na dnie owrzodzenia widoczne są krostki $[2,3]$.

Owrzodzenie jest czasami poprzedzone naciekiem zapalnym lub zmianą torbielowatą [4]. Zmiany skórne ustępują, a po wygojeniu pozostawiają widoczne blizny z licznymi niewielkimi otworkami i zagłębieniami, przypominające sito [2, 3]. Jednym z objawów piodermii zgorzelinowej jest zjawisko patergii, czyli zmienionej odczynowości, polegające na pojawieniu się zmian skórnych pod wpływem urazu (często bardzo niewielkiego). Szacuje się, że patergia dotyczy 25\% przypadków piodermii zgorzelinowej. Brak prawidłowego rozpoznania i podjęcie radykalnego leczenia chirurgicznego skutkuje rozszerzaniem się zmian obwodowo [5]. Oznacza to, że podejrzenie piodermii zgorzelinowej stanowi przeciwwskazanie do wykonywania jakichkolwiek zabiegów chirurgicznych ze względu na ich potencjalnie niekorzystny wpływ na przebieg choroby. Piodermii zgorzelinowej często towarzyszą choroby układowe, takie jak nieswoiste zapalenie jelit, autoimmunologiczne choroby tkanki łącznej, nowotwory złośliwe narządów wewnętrznych i układu krwiotwórczego, zwłaszcza zespoły mieloproliferacyjne, ostre i przewlekłe białaczki szpikowe oraz szpiczak mnogi [6, 7]. Przebieg piodermii zgorzelinowej zależy od współwystępowania innych chorób, a także rokowania związanego z chorobą podstawową. Jeśli choroba podstawowa jest uleczalna, rokowanie jest dobre, w przeciwnym przypadku terapia jest znacznie utrudniona.

\section{CEL PRACY}

Przedstawienie przypadku pacjentki z piodermią zgorzelinową współistniejącą z zespołem mieloproliferacyjnym oraz progresji choroby w wyniku interwencji chirurgicznej. 


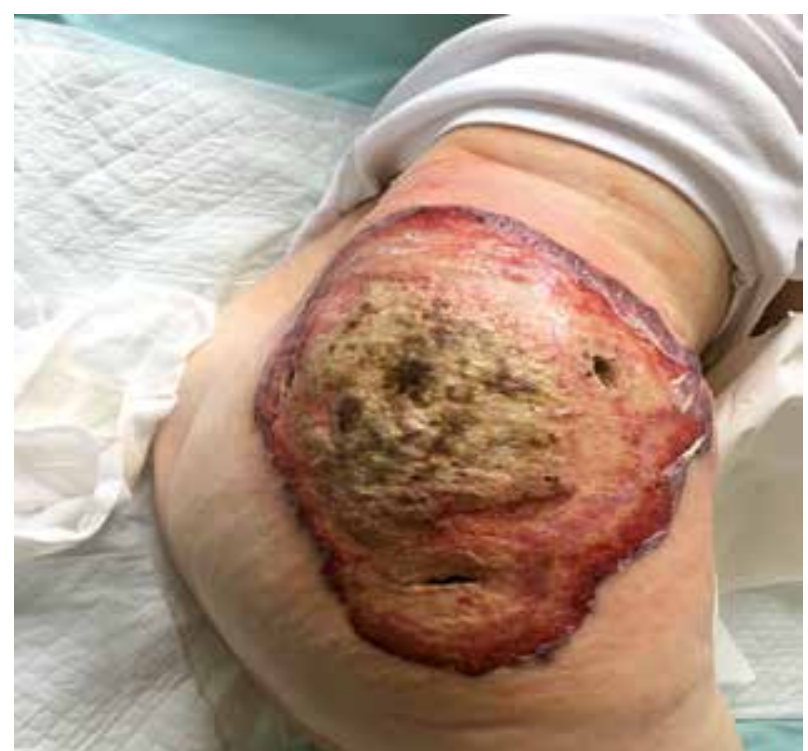

Figure I. Large ulceration with necrotic ulcer bed and purple circumference on the right buttock and right hip. Three incisions after a surgical intervention are visible

Rycina I. Rozległe owrzodzenie z martwiczym dnem, fioletowe na obwodzie, umiejscowione na prawym pośladku i prawym biodrze. Widoczne trzy nacięcia po interwencji chirurgicznej

of an ulceration of the right buttock after a surgical intervention (fig. 1). The inflammatory infiltration of the right buttock probably occurred after an intramuscular injection of meloxicam due to spine pain. Additionally, the patient had a fever of $40^{\circ} \mathrm{C}$ and was weak; pneumonia of the right side was diagnosed and treated with antibiotic therapy in hospital conditions. Due to the progression of the disorder of the right buttock in the Surgical Ward in Nysa an incision was made and the muscles of the right buttock were drained. The infiltration with a progressing necrosis of the right buttock was still present and progressing. Computed tomography scan eliminated the possibility of a buttock abscess. The patient was transferred to the Dermatologic Ward. During the admission process a large ulceration with necrotic bottom and blue circumference was diagnosed on the right buttock and right hip. Three incisions after a surgical intervention were visible. Lab test showed the following deviations: increased D-dimers $1.22 \mathrm{~g} / \mathrm{ml}$ (norm < 0.5), increased concentration of C-reactive protein $136.2 \mathrm{mg} / 1$ (norm < 5.0), elevated erythrocyte sedimentation rate $96 \mathrm{~mm}$, increased procalcitonin $0.275 \mathrm{ng} / \mathrm{ml}$ (norm < 0.05 ), low white blood cells $3.44 \times 10^{3} / \mu \mathrm{l}$, red blood cells $2.58 \times 10^{6} / \mu \mathrm{l}$, heamoglobin $7.8 \mathrm{~g} / \mathrm{dl}$, platelets per citrate $25 \times 10^{3} / \mu \mathrm{l}$ without the features of thrombocytopenic purpura; differential showed increased neutrophils $72 \%$, decreased band cells $1.2 \%$, large platelets $8.4 \%$. Additionally, decreased albumin and higher level of liver enzymes aspartate transaminase $34 \mathrm{U} / \mathrm{l}$, alanine transaminase $50 \mathrm{U} / 1$ were noted. During previous hospitalization at

\section{OPIS PRZYPADKU}

Kobieta 78-letnia została przyjęta na oddział dermatologii w lutym 2018 roku z powodu postępującego owrzodzenia w obrębie prawego pośladka po zabiegu chirurgicznym (ryc. 1). Naciek zapalny umiejscowiony na prawym pośladku wystąpił prawdopodobnie po domięśniowej iniekcji meloksykamu z powodu bólu kręgosłupa. Dodatkowo u pacjentki stwierdzono gorączkę sięgającą $40^{\circ} \mathrm{C}$ i osłabienie. Rozpoznano prawostronne zapalenie płuc i wdrożono antybiotykoterapię $\mathrm{w}$ warunkach szpitalnych. W związku z progresją zmiany na skórze prawego pośladka na Oddziale Chirurgii Szpitala w Nysie wykonano nacięcie i drenaż mięśni. Naciek z postępującą martwicą na prawym pośladku był jednak nadal obecny, z widoczną progresją. Za pomocą tomografii komputerowej wykluczono ropień pośladka. Pacjentka została przeniesiona na oddział dermatologii. Przy przyjęciu stwierdzono rozległe owrzodzenie z martwiczym dnem, sine na obwodzie, umiejscowione na prawym pośladku i prawym biodrze. Widoczne były również trzy nacięcia po przeprowadzonej interwencji chirurgicznej. W badaniach laboratoryjnych stwierdzono następujące odchylenia: podwyższony poziom D-dimerów - 1,22 g/ml (norma < 0,5), zwiększone stężenie białka C-reaktywnego - 136,2 mg/l (norma < 5,0), przyspieszone OB - $96 \mathrm{~mm}$, podwyższone stężenie prokalcytoniny $-0,275 \mathrm{ng} / \mathrm{ml}($ norma $<0,05)$, małą liczbę białych krwinek $-3,44 \times 10^{3} / \mu l$, czerwonych krwinek $-2,58 \times 10^{6} / \mu \mathrm{l}$, hemoglobiny $-7,8 \mathrm{~g} / \mathrm{dl}$, plytek pobieranych na cytrynian $-25 \times 10^{3} / \mu$ l, bez cech plamicy małopłytkowej; w rozmazie wzrost liczby neutrofilów $-72 \%$, 


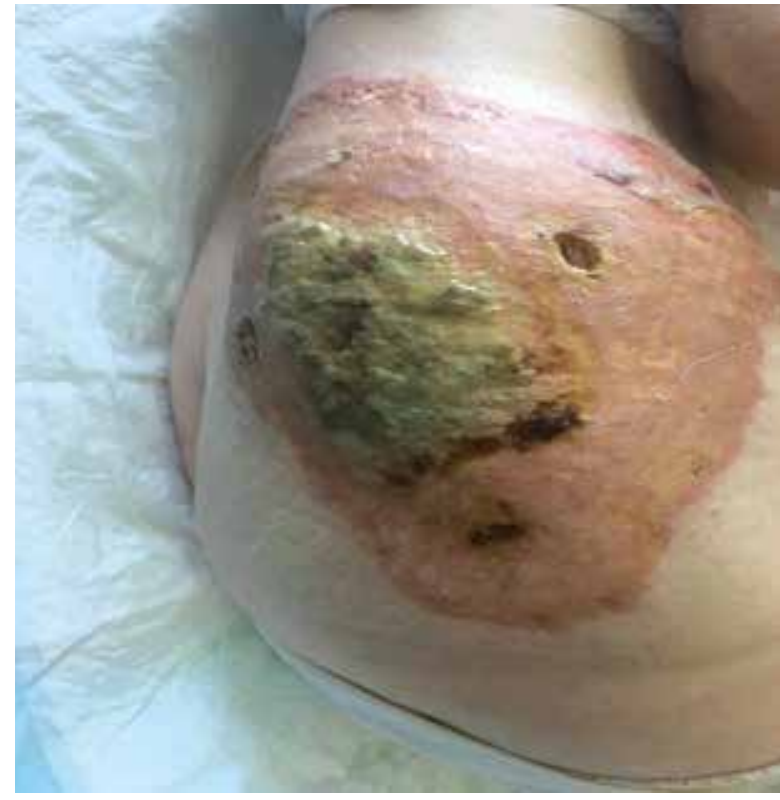

Figure 2. Regress of ulceration with a reduction of erythema in circumference after 5 pulses of methylprenisolone 500 mg/day

Rycina 2. Ustąpienie owrzodzenia z redukcją rumienia na obwodzie zmiany po podaniu 5 pulsów metyloprenizolonu w dawce $500 \mathrm{mg} /$ dobę

the Internal Medicine Ward in January 2018 imaging procedure, i.e. USG of the abdomen and tumor markers were within the norm. The patient was consulted hematologically - further hematological diagnostics for myeloproliferative diseases is necessary. Treatment included antibiotic therapy cefepime $1.0 \mathrm{~g}$ i.v. every 8 hours, pulses of methylprednisolone $500 \mathrm{mg}$ i.v./day for 5 days, prednisone dose of $40 \mathrm{mg}$ / day and topical glucocorticosteroid ointments and specialized dressings resulting in an improvement of morphotic parameters, general and local condition (fig. 2). The patient was discharged in good condition with an indication to broaden the hematological diagnostics for myeloproliferative diseases. The patient is constantly monitored by dermatological and hematological clinics, where further regression of the disorder is being observed (fig. 3).

\section{DISCUSSION}

Pyoderma gangrenosum is a neutrophilic dermatosis with unclear etiology. Common concurrence of pyoderma gangrenosum with autoimmune disorders and presence of pathergy suggest a role of the immunological system in the disease [8]. Involvement in the pathophysiological mechanism of the disease has been attributed to cellular and humoral immunity disorders, as well as defective function of monocytes and neutrophils [9-11]. In 50\% of cases the disease is preceded by a small injury, such as a needle prick or

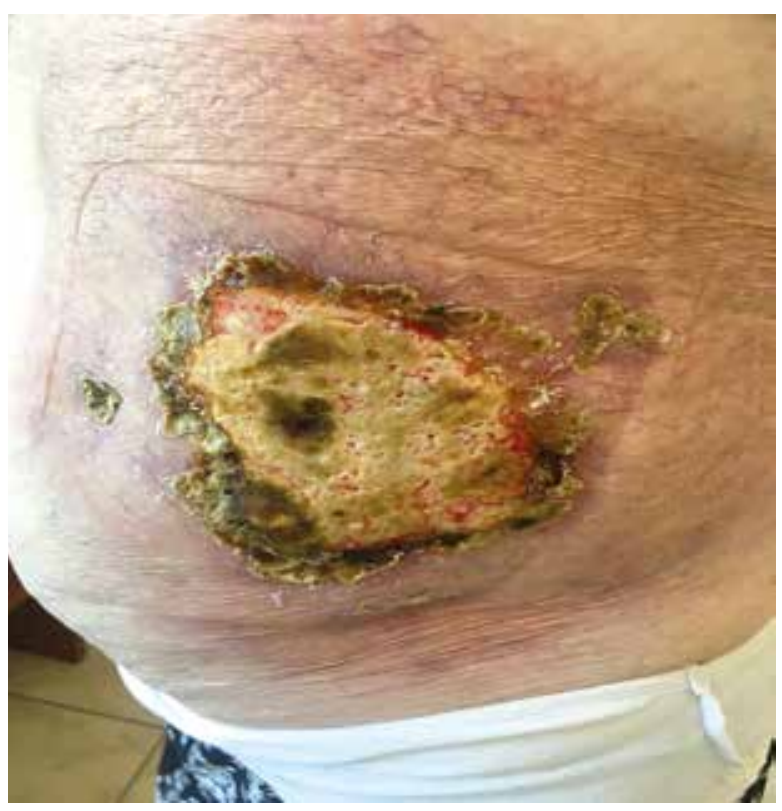

Figure 3. Three months after hospitalization and treatment with prednisone p.o. and specialized dressings

Rycina 3. Obraz po 3 miesiącach od hospitalizacji, po leczeniu prednizonem doustnie i stosowaniu opatrunków specjalistycznych

zmniejszenie liczby granulocytów obojętnochłonnych pałeczkowatych - 1,2\%, duże płytki krwi - 8,4\%. Dodatkowo stwierdzono zmniejszone stężenie albumin i zwiększone stężenie enzymów wątrobowych: aminotransferazy asparaginianowej - $34 \mathrm{U} / 1$ i alaninowej 50 U/1. Podczas wcześniejszej hospitalizacji na oddziale internistycznym w styczniu 2018 roku wykonano badanie obrazowe (USG jamy brzusznej) oraz analizę markerów nowotworowych. Nie stwierdzono nieprawidłowości. Pacjentka była konsultowana hematologicznie, jednak niezbędna jest dalsza diagnostyka w kierunku zespołu mieloproliferacyjnego. W leczeniu zastosowano antybiotykoterapię - cefepim w dawce 1,0 g dożylnie co 8 godzin, metyloprednizolon w pulsach dożylnych w dawce $500 \mathrm{mg} /$ dobę przez $5 \mathrm{dni}$, prednizon w dawce $40 \mathrm{mg} /$ dobę, a także miejscowe maści glikokortykosteroidowe i opatrunki specjalistyczne. Uzyskano poprawę parametrów morfotycznych, a także stanu ogólnego i miejscowego (ryc. 2). Pacjentka została wypisana w stanie ogólnym dobrym z zaleceniem rozszerzenia diagnostyki hematologicznej w kierunku zespołu mieloproliferacyjnego. Kobieta jest pod stałą opieką poradni dermatologicznej i hematologicznej, gdzie monitorowane jest ustępowanie choroby (ryc. 3).

\section{OMÓWIENIE}

Piodermia zgorzelinowa jest chorobą z grupy dermatoz neutrofilowych o niewyjaśnionej etiologii. Częste współwystępowanie piodermii zgorzelinowej z za- 
an insect bite (pathergy symptoms). In the case described above pyoderma gangrenosum progressed probably after an injection of an anti-inflammatory drug into the right buttock. Misdiagnosis of pyoderma gangrenosum is nothing surprising (over 10\%) [12]. Pyoderma gangrenosum is often misdiagnosed as an infection of a post-surgical wound, and the medical procedures (mechanical cleaning, cutting the wound, drainage) worsen the disease process in the pathergy mechanism, whereas antibiotic therapy and cleaning of the wound do not stop rapid growth of the ulceration $[8,13]$. In our patient, surgical interventions, such as incisions and draining of the right buttock muscles, caused spreading of pyoderma gangrenosum. In over $50 \%$ of cases pyoderma gangrenosum is accompanied by systemic disease. Non-specific enterocolitis is the most common accompanying disease. In around $7 \%$ of cases rheumatic diseases are present, whereas in around $1 \%$ of pyoderma gangrenosum cases hematological diseases develop, e.g. leukemia, polycythemia, myelofibrosis, essential thrombocytosis, multiple myeloma, most often an acute and chronic leukemic myelosis, whereas myeloproliferative disorder is not so often connected with pyoderma gangrenosum [14]. Myeloproliferative disorder mainly occurs in 60-year-old and above patients and usually causes acute cytopenia. We distinguish 5 basic types of myeloproliferative disorder, which differ in cytological features and the number of blasts in bone marrow smears and peripheral blood. It transforms into acute leukemic myelosis in $6 \%$ to $37 \%$ of patients with myeloproliferative disorder. Different skin disorders can occur with myeloproliferative disorder. We distinguish typical and atypical disorders in myeloproliferative disorder. The typical ones are an effect of an invasion of the skin by malignant hematopoietic system cells. Clinical symptoms include papules, phymas or nodules. The atypical ones include infections, vessel inflammation and neutrophilic dermatoses, including pyoderma gangrenosum [15]. The occurrence of dermatosis in a patient treated for a hematopoietic system disorder usually means a recurrence of a disease or its severe transformation and is a bad prognostic sign. Neutrophilic dermatoses, especially when they recur, can precede the development of myeloproliferative disorder by 2-8 years [16]. Due to the rarity of the disease and an uncertain etiology there are no treatment standards in the literature, and the choice of treatment depends on the clinical image, concurrent diseases and the general condition of a patient [17]. Usually, systemic therapy with a topical treatment, using, among others, systemic glucocorticosteroids with antibiotics, tacrolimus, cyclosporine, sulfasalasine, $10 \%$ silver nitrate, $1 \%$ sodium cromoglicate, is recommended. In the first-line treatment many authors proposes sys- burzeniami autoimmunologicznymi oraz zjawisko patergii wskazują na udział układu immunologicznego w rozwoju tej choroby [8]. Istotną rolę w mechanizmie patofizjologicznym schorzenia przypisuje się zaburzeniom odporności komórkowej i humoralnej, a także nieprawidłowej czynności monocytów i neutrofilów [9-11]. W 50\% przypadków chorobę poprzedza niewielki uraz, np. ukłucie igłą czy ukąszenie owada (objawy patergii). W przedstawionym przypadku piodermia zgorzelinowa rozwinęła się prawdopodobnie po iniekcji leku przeciwzapalnego w prawy pośladek. Stosunkowo często (u ponad $10 \%$ chorych) piodermia zgorzelinowa jest nieprawidłowo diagnozowana [12]. Schorzenie jest często błędnie rozpoznawane jako zakażenie rany pooperacyjnej, a procedury medyczne (oczyszczanie mechaniczne, nacinanie rany, drenaż) powodują nasilenie procesu chorobowego $\mathrm{w}$ mechanizmie patergii, przy czym antybiotykoterapia i oczyszczanie rany nie zatrzymują szybkiego rozprzestrzeniania się owrzodzenia [8, 13]. U przedstawionej pacjentki interwencje chirurgiczne (nacięcia i drenaż mięśni prawego pośladka), spowodowały rozszerzenie choroby. W ponad $50 \%$ przypadków piodermii zgorzelinowej towarzyszy choroba układowa. Najczęstszą chorobą towarzyszącą jest nieswoiste zapalenie jelit. W ok. 7\% przypadków występują schorzenia reumatyczne, natomiast u ok. $1 \%$ pacjentów $\mathrm{z}$ piodermią zgorzelinową stwierdza się choroby hematologiczne, takie jak białaczka, policytemia, mielofibroza, nadpłytkowość samoistna i szpiczak mnogi. Najczęściej jest to ostra i przewlekła białaczka szpikowa, natomiast współwystępowanie zespołu mieloproliferacyjnego z piodermią zgorzelinową obserwuje się rzadziej [14]. Zespół mieloproliferacyjny występuje głównie u pacjentów w wieku od 60 lat i zazwyczaj powoduje ostrą cytopenię. Wyróżnia się 5 podstawowych typów zespołu mieloproliferacyjnego, które różnią się obrazem cytologicznym oraz liczbą komórek blastycznych w rozmazie szpiku kostnego i krwi obwodowej. U 6-37\% pacjentów zespół mieloproliferacyjny ewoluuje w ostrą białaczkę szpikową. U chorych z zespołem mieloproliferacyjnym mogą występować różne schorzenia skóry. Zespołom mieloproliferacyjnym może towarzyszyć szereg typowych i atypowych zaburzeń. Typowe zaburzenia są skutkiem naciekania skóry przez zmienione nowotworowo komórki układu krwiotwórczego. Objawy kliniczne obejmują występowanie grudek, zmian przerostowych typu phyma lub guzków. Do atypowych schorzeń należą: zakażenia, zapalenie naczyń i dermatozy neutrofilowe, m.in. piodermia zgorzelinowa [15]. Występowanie dermatozy u pacjenta leczonego z powodu schorzenia układu krwiotwórczego zazwyczaj oznacza nawrót choroby lub jej transformację z pogorszeniem stanu i stanowi niekorzystny czynnik prognostyczny. Dermatozy neutrofilowe, zwłaszcza nawracające, mogą poprzedzać rozwój zespołu mieloproliferacyjnego o 2-8 lat [16]. Ze względu na rzadkie występowanie choroby i jej 
temic glucocorticosteroid, prednisone $0.5-1.0 \mathrm{mg} /$ $\mathrm{kg}$ body mass/day or methylprednisolone $0.8 \mathrm{mg} /$ $\mathrm{kg}$ body mass/day p.o., and in a rapidly developing disease pulses of methylprednisolone of $500 \mathrm{mg}$ i.v. for 3-5 days. The steroid treatment is then continued with, e.g. prednisone $40-60 \mathrm{mg} /$ day for around 56 months, and then the dose is gradually reduced [18]. In the described patient, due to the rapid progression of the ulceration and concurrent hematological disorders, it was decided to implement pulses of methylprednisolone i.v. $500 \mathrm{mg} /$ day for 5 days, then prednisone $40 \mathrm{mg}$ / day and topical glucocorticosteroid ointments and specialized dressing, which resulted in an improvement of morphotic parameters, achieving rapid improvement of the local condition and hematological parameters. Systemic glucocorticosteroid was beneficial not only in reducing the ulceration but also in improving the hematological parameters of myeloproliferative disorder.

\section{CONCLUSIONS}

Pyoderma gangrenosum is often accompanied by systemic diseases, which is why a holistic approach to a patient and looking for concurrent diseases and their treatment are important. Correct diagnosis of the disease prevents unnecessary surgical interventions, which more often than not lead to ulceration progression. Due to the lack of treatment standards, the choice is individual and depends upon the severity of the skin disorders, general condition of a patient, and concurrent diseases. In the presented patient the morphological changes and pathergy pointed to pyoderma gangrenosum, and the morphotic image and broad hematological diagnostics pointed to the concurrence of myeloproliferative disorder. The implementation of glucocorticosteroid pulses led to a quick improvement of the clinical condition. The patient required constant dermatological and hematological monitoring.

\section{CONFLICT OF INTEREST}

The authors declare no conflict of interest. niewyjaśnioną etiologię $\mathrm{w}$ dostępnym piśmiennictwie nie ma ustalonych standardów leczenia, a wybór terapii zależy od obrazu klinicznego, chorób współistniejących i ogólnego stanu pacjenta [17]. Zazwyczaj zalecana jest terapia ogólna w skojarzeniu z leczeniem miejscowym, m.in. z zastosowaniem ogólnych glikokortykosteroidów i antybiotyków, takrolimusu, cyklosporyny A, sulfasalazyny, $10 \%$ azotanu srebra, chromoglikanu sodowego $1 \%$. W leczeniu pierwszego wyboru wielu autorów zaleca glikokortykosteroid ogólny - prednizon w dawce 0,5-1,0 mg/kg m.c. lub metyloprednizolon w dawce $0,8 \mathrm{mg} / \mathrm{kg}$ m.c./dobę doustnie, a w przypadkach szybkiej progresji choroby metyloprednizolon $\mathrm{w}$ dawce 500 mg w pulsach dożylnych przez 3-5 dni. Następnie kontynuuje się leczenie glikokortykosteroidami, np. prednizonem w dawce 40-60 mg/dobę przez ok. 56 miesięcy, a potem stopniowo zmniejsza się dawkę [18]. U przedstawionej pacjentki - ze względu na szybko postępujące owrzodzenie i współistniejące zaburzenia hematologiczne - podjęto decyzję o wdrożeniu metyloprednizolonu w pulsach dożylnych w dawce $500 \mathrm{mg} /$ dobę przez $5 \mathrm{dni}$, następnie prednizonu w dawce $40 \mathrm{mg}$ / dobę oraz miejscowych maści glikokortykosteroidowych i opatrunków specjalistycznych. Uzyskano normalizacje parametrów morfotycznych, a także szybką poprawę stanu miejscowego i parametrów hematologicznych. Dzięki wdrożeniu ogólnego leku glikokortykosteroidowego osiągnięto nie tylko zmniejszenie owrzodzenia, lecz także poprawę parametrów hematologicznych w zespole mieloproliferacyjnym.

\section{WNIOSKI}

Piodermii zgorzelinowej często towarzyszą choroby układowe. Z tego względu istotne jest holistyczne podejście do pacjenta, poszukiwanie chorób współistniejących oraz ich leczenie. Właściwe rozpoznanie tej jednostki chorobowej zapobiega zbędnym interwencjom chirurgicznym, które najczęściej prowadzą do progresji owrzodzenia. Ze względu na brak ustalonych standardów leczenia wybór terapii jest indywidualny i zależy od stopnia nasilenia zamian skórnych, stanu ogólnego pacjenta i chorób współistniejących. U przedstawionej pacjentki obraz morfologiczny zmian oraz zjawisko patergii świadczyły o piodermii zgorzelinowej, a obraz morfotyczny oraz rozszerzona diagnostyka hematologiczna wskazywały na współistnienie zespołu mieloproliferacyjnego. Po wdrożeniu leczenia glikokortykosteroidami w postaci pulsów uzyskano szybką poprawę stanu klinicznego. Pacjentka wymagała stałej obserwacji w poradni dermatologicznej i hematologicznej.

\section{KONFLIKT INTERESÓW}

Autorzy nie zgłaszają konfliktu interesów. 


\section{References}

\section{Piśmiennictwo}

1. Marzano A.V., Cugno M., Trevisan V., Fanoni D., Venegoni L., Berti E., et al.: Role of inflammatory cells, cytokines and matrix metalloproteinases in neutrophil-mediated skin diseases. Clin Exp Immunol 2010, 162, 100-107.

2. Burgdorf W.H.C., Plewig G., Wolff H.H., Landthaler M.: Dermatologia Braun-Falco. Wydawnictwo Czelej Lublin, 2010, 917-919.

3. Wolff K., Johnson R.A., Saavedra A.P.: Fitzpatrick Atlas i zarys dermatologii klinicznej. Wydawnictwo Czelej, Lublin, 2014, 111-114.

4. Jabłońska S., Majewski S.: Choroby skóry i choroby przenoszone drogą płciową. Wydawnictwo PZWL, Warszawa 2008, 326-327.

5. Kavanagh G.M., Savin J.A.: Dermatologia - ilustrowane repetytorium. Medycyna Praktyczna, Kraków 2003, 112.

6. Binus A.M., Qureshi A.A., Li V.W., Winterfield L.S.: Pyoderma gangrenosum: a retrospective review of patient characteristics, comorbidities, and therapy in 103 patients. Br J Dermatol 2011, 165, 1244-1250.

7. Muňoz P.S., Ugidos A.F., Montiel P.M., Yagüe T.M., Garrido C., Herruzo J.A.: Atypical pyoderma gangrenosum in inflammatory bowel disease. A severe diagnostic challenge. Rev Esp Enferm Dig 2009, 101, 585-587.

8. Jankowska-Konsur A., Maj J., Hryncewicz-Gwóźdź A.: Piodermia zgorzelinowa - badanie retrospektywne 30 pacjentów hospitalizowanych w Klinice Dermatologii, Wenerologii i Alergologii Akademii Medycznej we Wrocławiu w latach 2000-2010. Przegl Dermatol 2012, 99, 10-15.

9. Greenberg S.J., Jegasothy B.V., Johnson R.B., Lazarus G.S.: Pyoderma gangrenosum. Occurrence with altered cellular immunity and a circulating serum factor. Arch Dermatol 1982, 118, 498-502.

10. Jones R.R., Kobza Black A., Donaghy M., Moshtael O., Pinching A.J.: Defective monocyte function in pyoderma gangrenosum with IgG kappa paraproteinaemia. Clin Exp Immunol 1983, 52, 685-692.

11. Bentley-Phillips C.B., Cooper R.C., Hallett A.F.: Pharmacological modulation of neutrophil phagocytic function in a patient with recurrent sepsis, pyoderma gangrenosum and impaired phagocytosis. Br J Dermatol 1982, 106, 687-695.

12. Weenig R.H., Davis M.D.P., Darl P.R., Su W.P.: Skin ulcers misdiagnosed as pyoderma gangrenosum. N Engl J Med 2002, $347,1412-1418$

13. Ogata K., Takamori H., Ikuta Y., Tanaka H., Ozaki N., Hayashi H., et al.: Pyoderma gangrenosum in an abdominal surgical site: a case report. Surg Case Rep 2015, 1, 122.

14. Powell F.C., Collins S.: Pyoderma gangrenosum. Clin Dermatol 2000, 18, 283-293.

15. Aractingi S., Bachmeyer C., Miclea J.M., Verola O., Rousselot C.P., Dubertret L., et al.: Unusual specific cutaneous lesions in myelodysplastic syndromes. J Am Acad Dermatol 1995, 33, 187-191.

16. Wallach D., Vignon-Pennamen M.D.: From acute febrile neutrophilic dermatosis to neutrophilic disease: forty years of clinical research. J Am Acad Dermatol 2006, 55, 1066-1071.

17. Błaszczyk M., Jabłońska S.: Pyoderma gangrenosum: współistniejące schorzenia ogólnoustrojowe i możliwości terapeutyczne. Przegl Dermatol 2001, 88, 487-494

18. Tupikowska M., Kaniowski M., Gruber J., Musioł M., Maj J.: Piodermia zgorzelinowa, trudności diagnostyczne i terapeutyczne - opis dwóch przypadków imitujących raka piersi. Przegl Dermatol 2016, 103, 40-44.

Received: 1.04 .2019

Accepted: 8.08.2019

Otrzymano: $1.04 .2019 \mathrm{r}$.

Zaakceptowano: $8.08 .2019 \mathrm{r}$.

How to cite this article

Kapuśniak A., Czachor A., Wąsik G.: Pyoderma gangrenosum coexisting with a myeloproliferative disorder. Dermatol Rev/Przegl Dermatol 2020, 107, 44-51. DOI: https://doi.org/10.5114/dr.2020.93970. 